Estudos de Psicologia

1998, Vol 15, n $1,67-68$

\title{
Cartas entre Freud \& Pfister 1909 - 1939
}

\author{
Karin Wondracek \\ Psicanalista
}

Foram lançadas, na Bienal de São Paulo, as Cartas entre Freud \& Pfister 1909- 1939: Um diálogo entre psicanálise e fé religio- sa. Compiladas por Ernst Freud e Heinrich Meng, com prefácio de ambos e de Anna Freud.

Iniciando no apogeu da relação Freud__ Jung, as Cartas constituem um to- cante registro da história da psicanálise e dos últimos 30 anos da vida de Freud. Pfister, pastor e pedagogo em Zurique, chega a Freud por intermédio de Jung, e mostra-se fascinado com o potencial da psicanálise para a cura de almas.

A correspondência inicia com Pfister enviando um. trabalho sobre Alucinação e suicídio de alunos. Desde as primeiras linhas das Cartas percebemos a ternura com que o criador da psicanálise acolhe o religioso que busca entender a alma. E acompanha- mos como, pouco a pouco, os dois trocam idéias, textos e, acima de tudo, compartilham a vida. Visitam-se, presenteiam-se, fazem confidências e influenciam-se mutuamente. "Nenhuma outra visita, desde a de Jung, fez-me tanto bem", escreve Freud. "O lugar mais aprazioel da terra? Informem-se na

1. Cartas entre Freud \& Pfister1909-1939: Diálogos entre psicanálise e fé cristã. Viçosa, Ultimato/Corpo de Psicólogos e Psiquiatras Cristãos, 1998.

Endereço para correspondência: Rua Carlos Von Koseritz, 1336, CEP 90540-030, Porto Alegre, RS, Fone/Fax: (051) 342.7606, E-Mail: merton@sogi- pa.esp.br

casa do Professor Freud" indica Pfister. O cotidiano da família Freud é delineado em tons róseos pelo amigo pastor; cenas domésticas partilham do conteúdo das Cartas ao lado de interessantes temas da teoria e técnica psicanalítica.

Pfister, membro fundador da Seção Zurique da Associação Psicanalítica Inter- nacional, toma parte ativa no movimento psicanalítico. Na calidez da amizade são compartilhadas situações que envolvem Jung, Adler, Abraham, Rank e outros pioneiros. Os primeiros passos da psicanálise tingem-se dos tons vivos das alegrias e ma- zelas humanas. Após a cisão com Jung, Pfister permanece como único freudiano em Zurique. Em 1919, é co-fundador daSo- ciedade Psicanalítica Suíça.

As Cartas relatam de que forma a singular combinação dos campos de atuação de Pfister vai produzindo impacto nos círculos atingidos. Revelam a abertura de pedagogos e teólogos para com a psicanálise e também as discussões enfrentadas nestes campos. Como um dos primeiros analistas laicos e de crianças, Pfister enfrenta as polêmicas sobre estas questões, e, encorajado por Freud, produz textos e palestras.

O fato de ambos serem escritores também propiciou que comentassem mui- tos aspectos da produção textual em psicanálise. Assim, podemos acompanhar a gestação e o nascimento de várias 
obras, os

Karin Wondracek

bastidores da editora psicanalítica, e apreciar o estímulo mútuo e os comentários críticos que a amizade franca proporcionava.

O auge da discussão teórica aparece nas cartas dos anos 1927 e 1928, em tomo do lançamento de O Futuro de uma Ilusão. Justamente a hábil combinação do relaciona- mento fecundo com a discussão de idéias proporciona uma visão mais abrangente do tema. É fascinante acompanhar o polêmico diálogo sobre o livro de Freud e o pro- cesso de geração do texto-resposta que Pfister denominou A Ilusão de um Futuro. "Eu o fiz com grande alegria, pois luto por uma amada causa com um amado adversário" (Pfister, carta de 20.2.28). É comovente sentir a abertura e, mais, ainda, o desejo de Freud em escutar o amigo que pensa diferente: " ... Alegro-me diretamente pelo seu posicionantenio público contra minha brochura, vai ser um refrigério em meio ao coro desafinado de críticas, para o qual estou preparado. Nós sabe- mos qlle por caminhos diferentes lutamos pelas mesmas coisas para os pobres homens." (Freud carta 81). Caminhos diferentes, mas entre- meados de consistentes pontes, que propiciaram este longo diálogo sobre psicanálise e visão de mundo, ética e religião. Troca fecunda que revitaliza questões novamente atuais.

O livro finaliza com a carta à viúva Martha Freud, na qual Pfister saudosamen- te discorre sobre a longa amizade e revela um desejo expressado por Freud a respeito do final da vida:

Nos últimos anos eu pensava com freqüência num trecho emocionante da carta de 6.3.1910. Creio que é meu dever compariillui-lo com a senhora. Ele é assim: "Não consigo imaginar como algo agradável viver sem trabalhar. Fantasiar e trabalhar coincidem para mim; nenhuma outra coisa me agrada tanto. Este seria umindício de felicidade, se não se inter-pusesse o pensamento assustador de que a produtividade depende totalmente de uma disposição muito deli-cada. Que se pode fazer num dia ou num tempo em que os pensamentos falham e as palavras não querem com- parecer? Não consigo livrarme de um tremor diante desta possibilidade. Por isso, mesmo rendendo-me inteira-mente ao destino como convém a uma pessoa honesta, tenho um pedido secreto: de modo algum uma enfermidade prolongada, nenhuma paralisia da capacidade produtiva por um sofrimento corporal. Morramos dentro da armadura, como diz o rei Macbeth." Realizou-se, pois, pelo menos o desejo de acuidade intelectual, de uma morte no capacete régio do pensador. 